\title{
Link between perceived oral and general health status among Yemeni adult dental patients
}

\author{
Mohammed Nasser Alhajj ${ }^{*}$ (D), Esam Halboub², Abdullah G. Amran ${ }^{3}$, Abdulaziz A. Alkheraif ${ }^{4}$, Fuad A. Al-Sanabani ${ }^{5}$, \\ Bandar M. Al-Makramani ${ }^{5}$, Abdulghani A. Al-Basmi ${ }^{6}$ and Fawaz A. Al-Ghabri ${ }^{3}$
}

\begin{abstract}
Background: Self-perceived health is an essential measure of health status and even a paramount predictor of mortality. So long as it is said that oral health $(\mathrm{OH})$ and general health $(\mathrm{GH})$ are mirrors to each other. This study sought to determine how Yemeni adults rate their $\mathrm{OH}$ and $\mathrm{GH}$, whether such a self-rating influenced by some potential risk factors, and whether both ratings $(\mathrm{OH}$ and $\mathrm{GH})$ are correlated.
\end{abstract}

Methods: A sample of 587 Yemeni dental patients aged 20 years and over were consecutively recruited. A structured interview form was used covering the following variables: age, gender, marital status, educational level, presence of dental prosthesis (DP), smoking and Qat chewing habits as independent variables, along with questions on "perceived oral health $(\mathrm{POH})$ " and "perceived general health $(\mathrm{PGH})$ " as dependent variables. The bivariate and multiple ordinal regression analyses were applied at $P$-value $<0.05$.

Results: Most of participants were women (73.6\%), and married (71.4\%), and more than half of them were young adults (58.2\%), with high educational levels (53.3\%), and not having DP. Only 310 participants responded to the questions on smoking and Qat chewing habits. Of these, $88.5 \%$ were non-smokers and $62.1 \%$ were Qat nonchewers. Up to $50 \%$ of the participants reported their $\mathrm{POH}$ as poor or fair, while lower proportions of participants (17\%) reported their PGH as such. Younger age (compared to elders), high education levels (compared to primary education) and being single (compared to married) significantly revealed better levels of $\mathrm{POH}$, while high education levels and being females significantly revealed better levels of PGH. Smoking and Qat chewing habits were found to have no effect on the perception of $\mathrm{POH}$ or $\mathrm{PGH}$. POH and PGH were found to be significantly correlated $(r=$ $0.486 ; P<0.001)$.

Conclusion: Higher levels of oral health problems can be anticipated among patients who perceive poor general health, and vice versa. The age, marital status and education were independent determinants of $\mathrm{POH}$, while the gender and education were independent determinants of PGH.

\section{Background}

Based on World Health Organization (WHO), health is defined as "a state of complete physical, mental and social well-being and not merely the absence of disease or infirmity" [1,2]. Although different definitions have also been suggested [3-6], they are still very broad, complex, and multidimensional $[4,5,7,8]$; no consensus on a single definition has been reached. Huber et al. [9]

\footnotetext{
* Correspondence: m.n.alhajj@hotmail.com

${ }^{1}$ Department of Prosthodontics, Faculty of Dentistry, Thamar University,

Dhamar, Yemen

Full list of author information is available at the end of the article
}

provided acceptable and concise definition for health as "the ability to adapt and to self-manage." The above argument is about health in general (General Health $[\mathrm{GH}])$ of which oral health $(\mathrm{OH})$ is an essential part. However, WHO [10] defined the latter as "a state of being free from mouth and facial pain, oral and throat cancer, oral infection and sores, periodontal (gum) disease, tooth decay, tooth loss, and other diseases and disorders that limit an individual's capacity in biting, chewing, smiling, speaking, and psychosocial wellbeing." For its part, the American dental association defines $\mathrm{OH}$ as "a functional, structural, aesthetic, physiologic and 
psychosocial state of well-being and is essential to an individual's general health and quality of life" [11].

As a rule, $\mathrm{GH}$ and $\mathrm{OH}$ cannot be viewed separately. Indeed, they are integral of each other; $\mathrm{OH}$ is considered as a mirror through which the $\mathrm{GH}$ is reflected in most instances. In fact, several systemic diseases have oral manifestations - might be as the early signs -, and many oral diseases have different effects on GH. For instance, many oral/periodontal pathogens have been reported to predispose to cardiovascular diseases [12, 13], and respiratory diseases such as chronic bronchitis, pneumonia, and chronic pulmonary obstructive disease (CPOD) $[14,15]$. In line with that, diabetic patients may develop severe inflammation of the gum and periodontal tissues, and presence of periodontal infection in these patients may exacerbate the case and complicate blood glucose control $[16,17]$. Although not particular to AIDS, oral candidiasis and necrotizing ulcerative periodontitis are diagnosed more frequently among these patients. [18]. Similarly, dysfunction of temporomandibular joint (TMJ) may be a part of a more generalized involvement - osteoarthritis for example -, and bone mass reduction in the mandible has been detected as a sign of osteoporosis $[19,20]$.

It can be noticed that all definitions of $\mathrm{GH}$ or $\mathrm{OH}$ are more than being free of diseases. They relates to many aspects in the individual's daily life. Presence of diseases, medications, functional ability, obesity, psychological wellbeing, and socioeconomic factors (alcohol consumption, smoking, etc.) can alter the individual's health status [21-23]. Health can be either subjectively perceived (self-rated) or assessed objectively by a physician using specific tools or indicators. Self-rated or perceived health is the summary of all information available to individual about his/her current health status [24, 25]. Perceived health can be measured by a single question: a) agecomparative question where subjects are asked to compare their health with someone else of the same age; b) timecomparative question where subjects are asked to compare their current health with that in the past; and c) noncomparative question where subjects are asked to rate their health at that moment $[26,27]$. The non-comparative question is the most commonly used in research and clinical practice. It is a simple question directed to the participants about their feelings about oral/general health status.

In this context, several studies have been conducted among different populations to address this issue with variable results. A study of Kotha et al. (2017) in Saudi Arabia revealed $75.1 \%$ of the participants rated their $\mathrm{OH}$ as excellent/very good/good; $24.9 \%$ rated their $\mathrm{OH}$ as poor to fair [28]. In South Africa, Olutola and AyoYusuf reported a proportion of $76.3 \%$ of their study sample rated their $\mathrm{OH}$ as good [29], almostly similar to what Andrade et al. (2012) reported among Brazilian sample
(74.36\%) [30]. Up to $83 \%$ of Australian adults sample who questioned by Mejia et al. (2014) rated their $\mathrm{OH}$ as good while it was reported only by $49 \%$ of an Indian sample [31,32] and by $58.3 \%$ of a Nigerian sample [33]. Assessment of patients' perception about their oral and general health is of utmost importance. It gives clear idea about the patients' feeling about their health. This can be reflected on the objective examination and ensure ideal or at least acceptable treatment from the patients' point of view. The aims of this study, therefore, were to determine how Yemeni adults rate their $\mathrm{OH}$ and $\mathrm{GH}$, and whether such a self-rating influenced by some potential risk factors.

\section{Methods}

The study was of a cross-sectional design in which the study population were dental patients attendees of outpatient clinics, Faculty of Dentistry, Thamar University, and three private clinics in Thamar city. During the period from June to September 2018, a consecutive sample comprised 587 participants were recruited. Eligibility criteria were: being 18 years old and above, Yemeni nationality, with no mental or physical disability. They were explicitly informed about the study objectives and procedure, and that the confidentiality of their data was guaranteed. Those who agreed to take a part in this study signed informed consents accordingly. The study was approved by the Ethical Committee, Thamar University, ahead of commencing its procedures (Ref: 2018019).

A structured interview form was used covering the following variables: age, gender, marital status, educational level, presence of dental prosthesis, smoking and Qat chewing habits as independent variables, along with the global single questions of "perceived oral health (POH)" (How do you rate your oral health status?) and "perceived general health (PGH)" (How do you rate your general health status?) as dependent variables. Responses to $\mathrm{POH}$ and PGH were scored as: $5=$ excellent, $4=$ very good, 3 =good, $2=$ fair, and 1 =poor. The age was categorized as: $\leq 20,21-30,31-40,41-50$, and $>50$ years. The educational status included illiterate, primary, preparatory, secondary, and university or above. The following dental prostheses (DP) were asked about: fixed DP, removable DP, implants, or more than one DP; responses to DP question were coded as: "yes" or "no". And similarly were coded the responses to smoking and Qat chewing.

\section{Statistical analysis}

Data were gathered, coded, and entered to a master sheet (Excel 2013, Microsoft). The statistical software SPSS V.25 (IBM Corp, Armonk, NY) was used for data analysis. For descriptive analysis, data were presented as frequency and percentage. Non-parametric tests were 
used for inferential analysis. Chi-squared test was used to test the potential association between $\mathrm{POH}$ and PGH, and between any of them (dependent variables) with the different study variables (independent variables). For the former test, contingency coefficient was checked and linear by linear results were selected. Additionally, Spearmen's correlation coefficient test was used to test the potential correlation between $\mathrm{POH}$ and PGH. Ordinal regression analysis with adjusted odds ratio (OR) was performed to explore the dependent determinants and the effect of the study variables on $\mathrm{POH}$ and PGH. All statistical tests were performed at a significant level $P$-value $<0.05$.

\section{Results}

Table 1 presents the characteristics of the participants. Out of 587, 73.6\% were women, 58.2\% were young adults ( $\leq 30$ years), and $71.4 \%$ were married. With regard to the education, secondary and university or above levels were reported more frequently (25.9 and $27.4 \%$, respectively). Up to $63 \%$ of participants reported not having PD. Only 310 participants responded to the questions on smoking and Qat chewing habits. Of these, 88.5\% were non-smokers and $62.1 \%$ were Qat nonchewers. Up to $50 \%$ of the participants reported their $\mathrm{POH}$ as poor or fair, while $30 \%$ reported good $\mathrm{POH}$. In contrast, up to $93 \%$ of the participants reported their PGH as good, very good or excellent.

Higher levels of POH (very good and excellent) were reported more frequently, with statistical significance, by young participants, males, singles, those who had higher levels of education and those who never wear dental prosthesis $(P<0.001$ each). Also to less extent, higher levels of $\mathrm{POH}$ (very good and excellent) were reported by nonsmokers, but it wasn't statistically significant $(P=0.051)$, and by Qat non-chewers with significant difference compared to Qat chewers ( $P=0.042$; Table 2$)$.

Responses of the participants to PGH question were almost similar to their responses to $\mathrm{POH}$ question. Overall, higher levels of PGH (good, very good and excellent) were reported more frequently by young participants $(P<0.001)$, males $(P=0.002)$, singles $(P<0.001)$, those who had higher levels of education $(\mathrm{P}<0.001)$ and those who never wear DP $(P=0.001)$. However, the associations of these responses with smoking and Qat chewing habits were not statistically significant $(P=0.904$ and 0.250 , respectively; Table 3 ). Single men, however, were found to report their oral and general health status better than single women $(P<0.05)$.

Table 4 crosstabulates the PGH against $\mathrm{POH}$. The lower levels of PGH (poor and fair) reported by the participants were significantly associated with lower levels of $\mathrm{POH}$. The vice versa applies to the higher levels of PGH and POH (very good and excellent; $P<0.001$ ). The
Table 1 Characteristics of the study sample ( $N=587$ unless otherwise stated)

\begin{tabular}{|c|c|c|}
\hline \multirow[t]{5}{*}{ Age } & $\leq 20$ years & $70(11.9)$ \\
\hline & $21-30$ years & $272(46.3)$ \\
\hline & $31-40$ years & $137(23.3)$ \\
\hline & $41-50$ years & $55(9.4)$ \\
\hline & $>50$ years & $53(9.0)$ \\
\hline \multirow[t]{2}{*}{ Gender } & Male & $155(26.4)$ \\
\hline & Female & $432(73.6)$ \\
\hline \multirow[t]{2}{*}{ Marital status } & Single & $168(28.6)$ \\
\hline & Married & $419(71.4)$ \\
\hline \multirow[t]{5}{*}{ Education } & Illiterate & $95(16.2)$ \\
\hline & Primary & $91(15.5)$ \\
\hline & Preparatory & $88(15.0)$ \\
\hline & Secondary & $152(25.9)$ \\
\hline & University or above & $161(27.4)$ \\
\hline \multirow[t]{2}{*}{ Dental prosthesis } & Yes & $216(36.8)$ \\
\hline & No & $371(63.2)$ \\
\hline \multirow[t]{2}{*}{ Smoking $(N=310)$} & Yes & $38(11.5)$ \\
\hline & No & $292(88.5)$ \\
\hline \multirow[t]{2}{*}{ Qat chewing $(N=310)$} & Yes & $125(37.9)$ \\
\hline & No & $205(62.1)$ \\
\hline \multirow[t]{5}{*}{ Perceived oral health } & Poor & $138(23.5)$ \\
\hline & Fair & $150(25.6)$ \\
\hline & Good & $175(29.8)$ \\
\hline & Very good & $93(15.8)$ \\
\hline & Excellent & $31(5.3)$ \\
\hline \multirow[t]{5}{*}{ Perceived general health } & Poor & $29(4.9)$ \\
\hline & Fair & 69 (11.8) \\
\hline & Good & $205(34.9)$ \\
\hline & Very good & $177(30.2)$ \\
\hline & Excellent & $107(18.2)$ \\
\hline
\end{tabular}

discrepancy of distribution was related to the "good" response. The Spearman's correlation coefficient was moderate but statistically significant $(r=0.486 ; P<0.001)$.

Results of the multiple ordinal regression analysis, as shown in Table 5, revealed better POH among young participants who aged $\leq 20$ and $21-30$ years old $(O R=$ 3.27, $\mathrm{CI}_{95 \%}=1.16-9.21$ and $3.1, \mathrm{CI}_{95 \%}=1.34-7.19 ; P=$ 0.025 and 0.008 , respectively) compared to those who aged > 50 years old. Participants who were singles showed twice chance of better $\mathrm{POH}$ compared to married participants $\left(O R=2.00, \quad \mathrm{CI}_{95 \%}=1.15-3.48 ; \quad P=\right.$ 0.014). Contrarily, the participants with lower levels of education (illiterate, primary and preparatory) revealed worse $\mathrm{POH}(\mathrm{OR}=0.22,0.32$ and $0.42 ; P<0.001,=0.001$ and 0.01 , respectively) compared to the participants who had university level or above. 
Table 2 The distribution of perceived oral health $(\mathrm{POH})$ according to the different variables ( $N=587$ unless otherwise stated)

\begin{tabular}{|c|c|c|c|c|c|c|c|}
\hline & & \multicolumn{5}{|c|}{ Perceived oral health } & \multirow[t]{2}{*}{$P$} \\
\hline & & Poor & Fair & Good & Very good & Excellent & \\
\hline \multirow[t]{5}{*}{ Age } & $\leq 20$ years & $10(14.3)$ & $16(22.9)$ & 27 (38.6) & $12(17.1)$ & $5(7.1)$ & \multirow[t]{5}{*}{$<.001$} \\
\hline & $21-30$ years & $61(22.4)$ & $53(19.5)$ & $85(31.3)$ & $53(19.5)$ & $20(7.4)$ & \\
\hline & $31-40$ years & $34(24.8)$ & $37(27.0)$ & 39 (28.5) & $22(16.1)$ & $5(3.6)$ & \\
\hline & $41-50$ years & $12(21.8)$ & $19(34.5)$ & $19(34.5)$ & $4(7.3)$ & $1(1.8)$ & \\
\hline & $>50$ years & 21 (39.6) & $25(47.2)$ & $5(9.4)$ & $2(3.8)$ & $0(0.0)$ & \\
\hline \multirow[t]{2}{*}{ Gender } & Male & 18 (11.6) & $46(29.7)$ & $53(34.2)$ & $22(14.2)$ & $16(10.3)$ & \multirow[t]{2}{*}{$<.001$} \\
\hline & Female & $120(27.8)$ & $104(24.1)$ & $122(28.2)$ & $71(16.4)$ & $15(3.5)$ & \\
\hline \multirow[t]{2}{*}{ Marital status } & Single & $22(13.1)$ & $35(20.8)$ & $56(33.3)$ & $42(25.0)$ & $13(7.7)$ & \multirow[t]{2}{*}{$<.001$} \\
\hline & Married & $116(27.7)$ & $115(27.4)$ & $119(28.4)$ & $51(12.2)$ & $18(4.3)$ & \\
\hline \multirow[t]{5}{*}{ Education } & Illiterate & $48(50.5)$ & $31(32.6)$ & $13(13.7)$ & $3(3.2)$ & $0(0.0)$ & \multirow[t]{5}{*}{$<.001$} \\
\hline & Primary & $28(30.8)$ & $33(36.3)$ & $21(23.1)$ & $7(7.7)$ & $2(2.2)$ & \\
\hline & Preparatory & $26(29.5)$ & $21(23.9)$ & $31(35.2)$ & $8(9.1)$ & $2(2.3)$ & \\
\hline & Secondary & $22(14.5)$ & $27(17.8)$ & 51 (33.6) & $35(23.0)$ & $17(11.2)$ & \\
\hline & University or above & $14(8.7)$ & $38(23.6)$ & 59 (36.6) & $40(24.8)$ & $10(6.2)$ & \\
\hline \multirow[t]{2}{*}{ Dental prosthesis } & Yes & 64 (29.6) & $67(31.0)$ & $67(31.0)$ & $17(7.9)$ & $1(0.5)$ & \multirow[t]{2}{*}{$<.001$} \\
\hline & No & $74(19.9)$ & $83(22.4)$ & $108(29.1)$ & $76(20.5)$ & $30(8.1)$ & \\
\hline \multirow[t]{2}{*}{ Smoking $(N=310)$} & Yes & $7(18.4)$ & $19(50.0)$ & $9(23.7)$ & $1(2.6)$ & $2(5.3)$ & \multirow[t]{2}{*}{0.051} \\
\hline & No & $54(18.5)$ & $74(25.3)$ & $103(35.3)$ & $48(16.4)$ & $13(4.5)$ & \\
\hline \multirow[t]{2}{*}{ Qat chewing $(N=310)$} & Yes & $27(21.6)$ & $43(34.4)$ & $36(28.8)$ & $12(9.6)$ & $7(5.6)$ & \multirow[t]{2}{*}{0.042} \\
\hline & No & 34 (16.6) & $50(24.4)$ & $76(37.1)$ & $37(18.0)$ & $8(3.9)$ & \\
\hline
\end{tabular}

Chi-square test was used; $\mathrm{POH}$ : perceived oral health

In context of $\mathrm{PGH}$, the multiple regression analysis, as shown in Table 6, revealed somewhat different results. Males reported better PGH compared to females $\left(\mathrm{OR}=1.61, \quad \mathrm{CI}_{95 \%}=1.10-2.35 ; \quad P=0.015\right)$. However, education stayed a significant determinant of PGH; the participants with lower levels of education (illiterate and primary) showed worse $\mathrm{PGH}(\mathrm{OR}=0.15$ and 0.28 , respectively, $P<0.001$ ) compared to those who had university level or above.

\section{Discussion}

To the best of our knowledge, this is the first study among Yemeni people that explored the relationship between $\mathrm{POH}$ and $\mathrm{PGH}$, and the relation of each of them with some sociodemographic variables and habits including smoking and Qat chewing. Overall, the correlation between $\mathrm{POH}$ and PGH was evident, similarly as were the relationships between these two measures and the other sociodemographic variables. Despite being not significant in the multiple ordinal regression analyses, higher proportions of Qat chewers and smokers rated their $\mathrm{POH}$ as poor and fair in comparison to their counterparts. This was not true with regard to PGH - Qat chewing and smoking habits didn't appear to be significant determinant of PGH.
In the current study, up to half of the participants (51\%) rated their $\mathrm{POH}$ as good, very good or excellent. This proportion is lower than that reported by other populations: Saudia Arabia (75.1\%) [28], South Africa (76.3\%) [29], Brazil (74.3\%) [30], Australia (83\%) [31], and Nigeria $(58.3 \%)$ [33]. Poor or fair $\mathrm{POH}$ were reported by $49 \%$ of participants. This proportion could be considered to be high and might be attributed to many factors like age, knowledge and practice of oral health, or cost of dental services. Moreover, this perception might be indifferent unless associated with pain or disfigurement. Contrariwise, only $16.7 \%$ of the study population rated their PGH as fair or poor - up to $83 \%$ rated it as good, very good and excellent. The former result is lower than that reported by Okanseri et al. among Somalian individuals (38\%) [34]. The diversity of results could be explained by the differences in participants' ages, health knowledge and awareness, and quality of health services among the different populations. Moreover, the lack of healthcare programs, low economic status, and poor nutrition among Yemeni population may reflect negatively on their responses. There might be a high tolerance to systemic diseases in a way that make Yemenis indifferent. Such a tolerance is not applied to oral diseases probably owing to the associated 
Table 3 The distribution of perceived general health $(\mathrm{PGH})$ according to the different variables ( $N=587$ unless otherwise stated)

\begin{tabular}{|c|c|c|c|c|c|c|c|}
\hline & & \multicolumn{5}{|c|}{ Perceived general health } & \multirow[t]{2}{*}{$P$} \\
\hline & & Poor & Fair & Good & Very good & Excellent & \\
\hline \multirow[t]{5}{*}{ Age } & $\leq 20$ years & $5(7.1)$ & $7(10.0)$ & $14(20.0)$ & $27(38.6)$ & $17(24.3)$ & \multirow[t]{5}{*}{$<.001$} \\
\hline & $21-30$ years & $11(4.0)$ & $26(9.6)$ & $86(31.6)$ & $85(31.3)$ & $64(23.5)$ & \\
\hline & $31-40$ years & $7(5.1)$ & $13(9.5)$ & $58(42.3)$ & $38(27.7)$ & $21(15.3)$ & \\
\hline & $41-50$ years & $2(3.6)$ & $13(23.6)$ & $20(36.4)$ & $17(30.9)$ & $3(5.5)$ & \\
\hline & $>50$ years & $4(7.5)$ & $10(18.9)$ & $27(50.9)$ & $10(18.9)$ & $2(3.8)$ & \\
\hline \multirow[t]{2}{*}{ Gender } & Male & $5(3.2)$ & $16(10.3)$ & $41(26.5)$ & $54(34.8)$ & $39(25.2)$ & \multirow[t]{2}{*}{0.002} \\
\hline & Female & $24(5.6)$ & $53(12.3)$ & $164(38.0)$ & $123(28.5)$ & $68(15.7)$ & \\
\hline \multirow[t]{2}{*}{ Marital status } & Single & $10(6.0)$ & $12(7.1)$ & $38(22.6)$ & $63(37.5)$ & $45(26.8)$ & \multirow[t]{2}{*}{$<.001$} \\
\hline & Married & $19(4.5)$ & 57 (13.6) & $167(39.9)$ & $114(27.2)$ & $62(14.8)$ & \\
\hline \multirow[t]{5}{*}{ Education } & Illiterate & $11(11.6)$ & $24(25.3)$ & $51(53.7)$ & $8(8.4)$ & $1(1.1)$ & \multirow[t]{5}{*}{$<.001$} \\
\hline & Primary & $5(5.5)$ & $18(19.8)$ & $42(46.2)$ & $16(17.6)$ & $10(11.0)$ & \\
\hline & Preparatory & $3(3.4)$ & $11(12.5)$ & $27(30.7)$ & 34 (38.6) & $13(14.8)$ & \\
\hline & Secondary & $6(3.9)$ & $12(7.9)$ & $44(28.9)$ & 45 (29.6) & 45 (29.6) & \\
\hline & University or above & $4(2.5)$ & $4(2.5)$ & $41(25.5)$ & $74(46.0)$ & 38 (23.6) & \\
\hline \multirow[t]{2}{*}{ Dental prosthesis } & Yes & $13(6.0)$ & $33(15.3)$ & $90(41.7)$ & $54(25.0)$ & $26(12.0)$ & \multirow[t]{2}{*}{$<.001$} \\
\hline & No & $16(4.3)$ & $36(9.7)$ & $115(31.0)$ & $123(33.2)$ & $81(21.8)$ & \\
\hline \multirow[t]{2}{*}{ Smoking $(N=310)$} & Yes & $0(0.0)$ & $5(13.2)$ & $17(44.7)$ & $11(28.9)$ & $5(13.2)$ & \multirow[t]{2}{*}{0.904} \\
\hline & No & $9(3.1)$ & $37(12.7)$ & $110(37.7)$ & $88(30.1)$ & $48(16.4)$ & \\
\hline \multirow[t]{2}{*}{ Qat chewing $(N=310)$} & Yes & $0(0.0)$ & $15(12.0)$ & $54(43.2)$ & $32(25.6)$ & $24(19.2)$ & \multirow[t]{2}{*}{0.250} \\
\hline & No & $9(4.4)$ & $27(13.2)$ & $73(35.6)$ & $67(32.7)$ & $29(14.1)$ & \\
\hline
\end{tabular}

Chi-square test was used; PGH: perceived general health

disability. Furthermore, the subjective rating has a chance of bias owing to individuals' variability in rating themselves [35].

In agreement with many previous studies [36, 37], younger Yemeni participants (21-30 years old) rated their oral and general health as being better than that of elders. This might be related to the fact that elder individuals become unable to maintain good oral hygiene. In addition, in comparison to young adults, elderly experience many age related health problems along with the physiologic changes of body organs that progress with age and decrease the ability of the body to tolerate and resist disease processes. For its part, the education was found to be an important determinant of perceived health status- both $\mathrm{PGH}$ and $\mathrm{POH}$. Individuals with higher education levels rated their oral health as being better than that of illiterate and low educational levels. It is well-known that educated persons have higher levels of knowledge, awareness, attitude and beliefs of health issues, have no difficulties in reading and/or understanding healthcare instructions, and they can easily get more facilities and resources to learn more. However, this result is in contrast with that of Kotha et al., who did not find association between education and $\mathrm{POH}$ [28].

In contrast to many previous studies [38, 39], our results revealed better PGH and $\mathrm{POH}$ among singles in comparison to the married individuals. However, our results were similar to that of Roherer et al. [38] who revealed better self-rated health among unmarried women in comparison to the married ones. On the other

Table 4 Correlation between responses to perceived oral and general health ( $\mathrm{POH}$ and $\mathrm{PGH})$ questions $(\mathrm{N}=587)$

\begin{tabular}{|c|c|c|c|c|c|c|c|c|}
\hline & & \multicolumn{5}{|l|}{$\mathrm{POH}$} & \multirow[t]{2}{*}{$P\left(x^{2}\right)$} & \multirow{2}{*}{$\begin{array}{l}\text { Spearman's } \\
\text { correlation }\end{array}$} \\
\hline & & Poor & Fair & Good & Very good & Excellent & & \\
\hline \multirow[t]{5}{*}{ PGH } & Poor & $20(69.0)$ & $5(17.2)$ & $2(6.9)$ & $1(3.4)$ & $1(3.4)$ & $<.001$ & $0.486, P<0.001$ \\
\hline & Fair & $28(40.6)$ & $25(36.2)$ & $13(18.8)$ & $3(4.3)$ & $0(0.0)$ & & \\
\hline & Good & $61(29.8)$ & 68 (33.2) & $64(31.2)$ & $11(5.4)$ & $1(0.5)$ & & \\
\hline & Very good & $17(9.6)$ & $39(22.0)$ & $71(40.1)$ & $44(24.9)$ & $6(3.4)$ & & \\
\hline & Excellent & $12(11.2)$ & $13(12.1)$ & $25(23.4)$ & $34(31.8)$ & $23(21.5)$ & & \\
\hline
\end{tabular}


Table 5 Ordinal regression for the effect of study variables on perceived oral health $(\mathrm{POH})$ status

\begin{tabular}{|c|c|c|c|c|c|c|c|}
\hline & & Estimate & Std. & OR & $95 \% \mathrm{Cl}$ & & Sig. \\
\hline & & & & & Lower & Upper & \\
\hline Age & $\leq 20$ years & 1.18 & 0.53 & 3.27 & 1.16 & 9.21 & 0.025 \\
\hline & $21-30$ years & 1.13 & 0.43 & 3.10 & 1.34 & 7.19 & 0.008 \\
\hline & $31-40$ years & 0.79 & 0.43 & 2.20 & 0.94 & 5.12 & 0.068 \\
\hline & $41-50$ years & 0.85 & 0.47 & 2.34 & 0.92 & 5.95 & 0.073 \\
\hline & $>50$ years & Reference & & & & & \\
\hline Gender & Male & 0.31 & 0.28 & 1.37 & 0.79 & 2.36 & 0.263 \\
\hline & Female & Reference & & & & & \\
\hline Marital status & Single & 0.69 & 0.28 & 2.00 & 1.15 & 3.48 & 0.014 \\
\hline & Married & Reference & & & & & \\
\hline Education & Illiterate & -1.51 & 0.42 & 0.22 & 0.10 & 0.50 & $<.001$ \\
\hline & Primary & -1.14 & 0.33 & 0.32 & 0.17 & 0.61 & 0.001 \\
\hline & Preparatory & -0.87 & 0.33 & 0.42 & 0.22 & 0.81 & 0.010 \\
\hline & Secondary & -0.18 & 0.29 & 0.84 & 0.47 & 1.49 & 0.551 \\
\hline & University or above & Reference & & & & & \\
\hline Dental prosthesis & Yes & -0.34 & 0.22 & 0.71 & 0.46 & 1.10 & 0.127 \\
\hline & No & Reference & & & & & \\
\hline Qat chewing & Yes & -0.30 & 0.25 & 0.74 & 0.46 & 1.21 & 0.230 \\
\hline & No & Reference & & & & & \\
\hline
\end{tabular}

Pseudo R-Square: Nagelkerke $=0.26$; Model Fitting Information: $\mathrm{X} 2=92.45, \mathrm{P}<0.001$

Table 6 Ordinal regression for the effect of study variables on perceived general health (PGH) status

\begin{tabular}{|c|c|c|c|c|c|c|c|}
\hline & & \multirow[t]{2}{*}{ Estimate } & \multirow{2}{*}{$\begin{array}{l}\text { Std. } \\
\text { Error }\end{array}$} & \multirow[t]{2}{*}{ OR } & \multicolumn{2}{|c|}{$95 \% \mathrm{Cl}$} & \multirow[t]{2}{*}{ Sig. } \\
\hline & & & & & Lower & Upper & \\
\hline \multirow[t]{5}{*}{ Age } & $\leq 20$ years & 0.31 & 0.40 & 1.36 & 0.63 & 2.97 & 0.436 \\
\hline & $21-30$ years & 0.36 & 0.33 & 1.43 & 0.76 & 2.72 & 0.269 \\
\hline & $31-40$ years & 0.23 & 0.33 & 1.25 & 0.66 & 2.38 & 0.488 \\
\hline & $41-50$ years & -0.14 & 0.36 & 0.87 & 0.42 & 1.77 & 0.691 \\
\hline & $>50$ years & Reference & & & & & \\
\hline \multirow[t]{2}{*}{ Gender } & Male & 0.47 & 0.19 & 1.61 & 1.10 & 2.35 & 0.015 \\
\hline & Female & Reference & & & & & \\
\hline \multirow[t]{2}{*}{ Marital status } & Single & 0.22 & 0.20 & 1.25 & 0.84 & 1.86 & 0.272 \\
\hline & Married & Reference & & & & & \\
\hline \multirow[t]{5}{*}{ Education } & Illiterate & -1.89 & 0.29 & 0.15 & 0.08 & 0.27 & $<.001$ \\
\hline & Primary & -1.28 & 0.26 & 0.28 & 0.17 & 0.46 & $<.001$ \\
\hline & Preparatory & -0.49 & 0.26 & 0.61 & 0.37 & 1.01 & 0.057 \\
\hline & Secondary & -0.16 & 0.21 & 0.85 & 0.56 & 1.29 & 0.447 \\
\hline & University or above & Reference & & & & & \\
\hline \multirow[t]{2}{*}{ Dental prosthesis } & Yes & -0.25 & 0.17 & 0.78 & 0.56 & 1.08 & 0.127 \\
\hline & No & Reference & & & & & \\
\hline
\end{tabular}


hand, Zeng and Thomas [39] in their study found that married individuals tend to overestimate their health status. This may be attributed to the fact that single subjects tend to care more and to look better. Typically, married individuals have more responsibilities and more important concerns that being given priorities over their health status. In context of relation with gender, more females than males reported poor oral and general health. Although this is the case in studies conducted by Szwarcwald et al. and Darviri et al. [36, 37], a possible explanation for this result might be that females usually pay more concern to their general health and oral appearance which may be reflected on their rating.

The bivariate analysis revealed a borderline significant difference $(P=0.051)$ in favor of non-smokers compared to smokers in reporting their oral health status. Such a finding, to some extent, confirms the results of many previous studies, suggesting a direct association between smoking and the prevalence and severity of mucosal, dental, and periodontal disease [40, 41]. However, upon adjusting with the multivariate analyses, the role of smoking was no longer evident. Otherwise, there was a significant difference in favor of Qat non-chewers compared to Qat chewers in relation to their oral health status. Although still controversial, there has been an increasing evidence on the negative effects of Qat on oral and dental conditions including white lesions, mucosal pigmentation, periodontal diseases, tooth loss, plasma cell stomatitis, and xerostomia [42, 43]. More specifically, in context of our study, Qat has been found to be associated with worse self-rated health, lower quality of life, and negative effect on the individual's general health [44-49]. The latter is not applied to our study where no significant difference was found between Qat chewers and non-chewers in reporting their general health status.

Multiple regression analyses confirmed the roles of age, gender, marital status, and education in determining the self-rated oral and general health. That is, older individuals, females, and lower educated individuals rated their health to be worse than that of their counterparts. Szwarcwal et al. [50] in their national health survey in Brazil, and Darviri et al. [37] in their study reported similar roles for the age, education and gender on perception of health status. Such results were also observed in many previous studies [51-53]. In contrast, Darker et al. [54] did not reported on effects of age, gender, and marital status on self-perception of health. As a rule, disparities in socioeconomic variables definitely lead to wide varieties in health perception [55-58]. As expected, the correlation between $\mathrm{POH}$ and $\mathrm{PGH}$ was significant; the better the $\mathrm{PGH}$, the better the $\mathrm{POH}$, and vice versa. So long as it is said that each is a mirror of the other. Oral health has been described as "the window to general health". In many instances, oral cavity may be the early site, and it reflects many signs, of many general systemic diseases like general infections, and nutritional deficiencies [59, 60]. Garcia et al. [61] reported that the greater the number of missing teeth the poorer the quality of life. In line with that, poor dentation leads to difficulty in mastication which ultimately results in poor nutritional intake. Although patients perceive their health statuses from a somewhat different point of view of that of the clinicians, their subjective assessment is of utmost importance and must not be ignored; rather it must be incorporated with the objective measures of disease. In addition, dental patients' report of their oral health status is a part of their overall reporting of general health status, although still within narrower limits when the general health is, let's say, reported by medical patients. That is, medical patients will concern more about their general health and treatment [62]. Aside from the measured determinants in this study, the differences in results can be also attributed to many notincluded determinants such as: health knowledge and awareness, socioeconomic status and the quality of health services among the different populations. In this context, the lack of healthcare programs, low economic status, and poor nutrition among Yemeni population may reflect negatively on their responses.

Although the study found a significant relationship between POH and PGH and also significant relations with some risk factors, it has some potential limitations. First, the external validity -generalizing the results to all Yemeni dental population- is not fully guaranteed owing to the fact that recruiting consecutive patients doesn't represent the population of interest. Second, no clinical examination was performed which can further support the relationship between subjective and objective measures. Third, the effect of the other sociodemographic factors, i.e. income and occupation, were not explored in this study. It is well known that Yemen is a poor developing country with a very low Human Development Index of 0.452 (ranked 178th) which entails substantial impact on Yemeni population health, and on health services. This implies, even partially, that most of the included participants might be from low income class, and such an inference must be considered cautiously when presenting our results. Lastly, the cross-sectional nature of the study which makes it difficult to explore the cause-effect relationship. Such limitations suggest further longitudinal follow-up and/or case-control studies which could be helpful in this matter.

Finally, the current situation that the Yemeni population are facing must be emphasized. Yemen goes through the world's largest humanitarian crisis that undoubtedly has a great effect on the individuals' perceptions of their oral and general health status. The International Committee of the Red Cross (ICRC) had a 
substantial concern about the high numbers of people needing treatment and about ongoing outbreaks of diseases such as cholera, diphtheria, and meningitis owing to the current war there [63].

\section{Conclusion}

Within the limitations of the current study, the following conclusions can be drawn:

- Higher levels of oral health problems can be anticipated among patients who perceive poor general health, and vice versa.

- The age, marital status and education were independent determinants of $\mathrm{POH}$, while the gender and education were independent determinants of PGH.

- To some extent, neither Qat chewing nor smoking habits appear to be relevant factors determining the perceived oral and general health status of the Yemeni dental patients.

\section{Abbreviations}

GH: General Health; ICRC: The International Committee of the Red Cross: $\mathrm{OH}$ : Oral Health; OHIP: Oral Health Impact Profile; OHRQoL: Oral HealthRelated Quality of Life; PGH: Perceived General Health; POH: Perceived Oral Health; QoL: Quality of Life

\section{Acknowledgements}

The authors are grateful to the Deanship of Scientific Research and Vice Deanship of Scientific Research Chairs, King Saud University.

\section{Authors' contributions}

MNA and ES participated in designing the study, statistical analysis, interpretation of the data and drafting the manuscript. AGA participated in designing the study, collection and interpretation of the data and drafting the manuscript. AAA, FAA and BMA participated in interpretation of the data and in drafting the manuscript. $A A B$ and FAA participated in designing the study, and collecting the data. All authors read and approved the final manuscript.

\section{Funding}

This study was funded by the Deanship of Scientific Research, King Saud University through the Vice Deanship of Scientific Research Chairs.

\section{Availability of data and materials}

The datasets supporting the findings of this article are available from the corresponding author.

\section{Ethics approval and consent to participate}

The study was approved by the Ethical Committee of Thamar University (Faculty of Dentistry) and written consent forms were signed by all participants.

\section{Consent for publication}

Not applicable.

\section{Competing interests}

The authors declare that they have no competing interests.

\section{Author details}

${ }^{1}$ Department of Prosthodontics, Faculty of Dentistry, Thamar University, Dhamar, Yemen. ${ }^{2}$ Department of Maxillofacial Surgery and Diagnostic Sciences, College of Dentistry, Jazan University, Jazan, Kingdom of Saudi Arabia. ${ }^{3}$ Department of Periodontics, Faculty of Dentistry, Thamar University, Dhamar, Yemen. ${ }^{4}$ Dental Biomaterials Research Chair, Dental Health Department, College of Applied Medical Sciences, King Saud University,
Riyadh, Kingdom of Saudi Arabia. ${ }^{5}$ Department of Prosthetic Dental Science, College of Dentistry, Jazan university, Jazan, Kingdom of Saudi Arabia.

${ }^{6}$ Private Dental Clinic, Dhamar, Yemen.

Received: 4 February 2019 Accepted: 20 May 2019

Published online: 28 May 2019

\section{References}

1. World Health Organization. What is the WHO Definition of Health? Available at: http://www.who.int/suggestions/faq/en/. Accessed 15 Jan 2019.

2. Callahan D. The WHO definition of 'Health'. Hast Cent Stud. 1973:1:77-87.

3. O'Donnell MP. Definition of health promotion 2.0: embracing passion, enhancing motivation, recognizing dynamic balance, and creating opportunities. Am J Health Promot. 2009;24:iv.

4. Williamson DL, Carr J. Health as a resource for everyday life: advancing the conceptualization. Crit Public Health. 2009;19:107-22.

5. Wang Y-L. A concept analysis of health. Hu li za zhi The journal of nursing. 2005:52:40-3.

6. Allen-Duck A, Robinson JC, Stewart MW. Healthcare quality: a concept analysis. Nurs Forum. 2017:52:377-86.

7. Song M, Kong EH. Older adults' definitions of health: a metasynthesis. Int J Nurs Stud. 2015:52:1097-106.

8. What is health? The ability to adapt. Lancet. 2009;373:781

9. Huber M, Knottnerus JA, Green L, et al. How should we define health? Bmj. 2011;343:d4163.

10. World Health Organization. Oral Health. Available at: http://www.who.int/ oral_health/publications/factsheet/en/. Accessed 21 Jan 2019.

11. American Dental Association. ADA Policy--Definition of Oral Health. Available at: https://www.ada.org/en/about-the-ada/ada-positions-policiesand-statements/ada-policy-definition-of-oral-health. Accessed 21 Jan 2019.

12. Desvarieux M, Demmer RT, Rundek T, et al. Relationship between periodontal disease, tooth loss, and carotid artery plaque: the Oral infections and vascular disease epidemiology study (INVEST). Stroke. 2003;34:2120-5.

13. Abnet CC, Qiao YL, Dawsey SM, et al. Tooth loss is associated with increased risk of total death and death from upper gastrointestinal cancer heart disease, and stroke in a Chinese population-based cohort. Int J Epidemiol. 2005:34:467-74

14. Terpenning MS, Taylor GW, Lopatin DE, et al. Aspiration pneumonia: dental and oral risk factors in an older veteran population. J Am Geriatr Soc. 2001; 49:557-63.

15. Azarpazhooh A, Leake JL. Systematic review of the association between respiratory diseases and oral health. J Periodontol. 2006;77:1465-82.

16. Lamster IB, Lalla $E$, Borgnakke WS, et al. The relationship between oral health and diabetes mellitus. J Am Dent Assoc. 2008;139 Suppl:19s-24s.

17. Perrino MA. Diabetes and periodontal disease: an example of an oral/ systemic relationship. N Y State Dent J. 2007;73:38-41.

18. Johnson NW, Glick M, Mbuguye TN. (A2) Oral health and general health Adv Dent Res. 2006:19:118-21.

19. Barbato L, Francioni E, Bianchi M, et al. Periodontitis and bone metabolism. Clin Cases Miner Bone Metab. 2015:12:174-7.

20. Schulze-Spate U, Turner R, Wang Y, et al. Relationship of bone metabolism biomarkers and periodontal disease: the osteoporotic fractures in men (MrOS) study. J Clin Endocrinol Metab. 2015;100:2425-33.

21. Manderbacka K, Lundberg O, Martikainen P. Do risk factors and health behaviours contribute to self-ratings of health? Soc Sci Med. 1999;48:1713-20.

22. Johansson SE, Sundquist J. Change in lifestyle factors and their influence on health status and all-cause mortality. Int J Epidemiol. 1999;28:1073-80.

23. Svedberg P, Bardage C, Sandin S, et al. A prospective study of health, lifestyle and psychosocial predictors of self-rated health. Eur J Epidemiol. 2006; 21:767-76.

24. Fayers PM, Sprangers MA. Understanding self-rated health. Lancet. 2002; 359:187-8.

25. Bombak AE. Self-rated health and public health: a critical perspective. Front Public Health. 2013;1:15.

26. Bjorner JB. Kristensen TS multi-item scales for measuring global self-rated health: investigation of construct validity using structural equations models. Res Aging. 1999:21:417-39.

27. Meng Q, Xie Z, Zhang T. A single-item self-rated health measure correlates with objective health status in the elderly: a survey in suburban Beijing Front Public Health. 2014;2:27. 
28. Kotha SB, Chaudhary M, Terkawi S, et al. Correlation of perceived self-rated Oral health status with various dental health and awareness factors. J Int Soc Prev Community Dent. 2017;7:S119-S124.

29. Olutola BG, Ayo-Yusuf OA. Socio-environmental factors associated with selfrated oral health in South Africa: a multilevel effects model. Int J Environ Res Public Health. 2012;9:3465-83.

30. Andrade FB, Lebrao ML, Santos $J$, et al. Factors related to poor selfperceived oral health among community-dwelling elderly individuals in Sao Paulo, Brazil. Cad Saude Publica. 2012;28:1965-75.

31. Mejia G, Armfield JM, Jamieson LM. Self-rated oral health and oral healthrelated factors: the role of social inequality. Aust Dent J. 2014;59:226-33.

32. Singh A, Purohit BM. Exploring patient satisfaction levels, self-rated oral health status and associated variables among citizens covered for dental insurance through a National Social Security Scheme in India. Int Dent J. 2017;67:172-9.

33. Olusile AO, Adeniyi AA, Orebanjo O. Self-rated oral health status, oral health service utilization, and oral hygiene practices among adult Nigerians. BMC Oral Health. 2014;14:140.

34. Okunseri C, Hodges JS, Born DO. Self-reported oral health perceptions of Somali adults in Minnesota: a pilot study. Int J Dent Hyg. 2008;6:114-8,

35. Peer E, Gamliel EJPA, Research, Evaluation too reliable to be true? Response bias as a potential source of inflation in paper-and-pencil questionnaire reliability. Pract Assess Res Eval. 2011;16:1-8.

36. Szwarcwald CL, Souza-Junior PR, Esteves MA, et al. Socio-demographic determinants of self-rated health in Brazil. Cad Saude Publica. 2005;21 Suppl:54-64.

37. Darviri C, Fouka G, Gnardellis C, et al. Determinants of self-rated health in a representative sample of a rural population: a cross-sectional study in Greece. Int J Environ Res Public Health. 2012;9:943-54.

38. Rohrer JE, Bernard ME, Zhang Y, et al. Marital status, feeling depressed and self-rated health in rural female primary care patients. J Eval Clin Pract. 2008; $14: 214-7$

39. Zheng $H$, Thomas PA. Marital status, self-rated health, and mortality: overestimation of health or diminishing protection of marriage? J Health Soc Behav. 2013:54:128-43.

40. Al-Tayar B, Tin-Oo MM, Sinor MZ, et al. Prevalence and association of smokeless tobacco use with the development of periodontal pocket among adult males in Dawan Valley, Yemen: a cross-sectional study. Tob Induc Dis. 2015;13:35.

41. Sreedevi M, Ramesh A. Dwarakanath C periodontal status in smokers and nonsmokers: a clinical, microbiological, and histopathological study. Int J Dent. 2012;2012:571590.

42. Halboub E, Dhaifullah E, Abdulhug M. Khat chewing and smoking effect on oral mucosa: a clinical study. Acta Med (Hradec Kralove). 2009;52:155-8.

43. Al-Alimi A, Halboub E, Al-Sharabi AK, et al. Independent determinants of periodontitis in Yemeni adults: a case-control study. Int J Dent Hyg. 2018;16:503-11.

44. Sheikh KA, El-Setouhy M, Yagoub $U$, et al. Khat chewing and health related quality of life: cross-sectional study in Jazan region, Kingdom of Saudi Arabia. Health Qual Life Outcomes. 2014;12:44.

45. Al-Maweri SA, Warnakulasuriya S, Samran A. Khat (Catha edulis) and its oral health effects: an updated review. J Investig Clin Dent. 2018;9:e12288.

46. Al-Akhali MS, Al-Moraissi EA. Khat chewing habit produces a significant adverse effect on periodontal, oral health: a systematic review and metaanalysis. J Periodontal Res. 2017;52:937-45.

47. Al-Maweri SA, AlAkhali M. Oral hygiene and periodontal health status among khat chewers. A case-control study. J Clin Exp Dent. 2017:9:e629-34.

48. El-Zaemey S, Schüz J, Leon M. Qat chewing and risk of potentially malignant and malignant oral disorders: a systematic review. Int J Occup Environ Med. 2015;6:129-43.

49. Walle M. Khat chewing and self rated oral health out comes in Bahir Dar, North West Ethiopia. Am J Health Res. 2014;2:344-9.

50. Szwarcwald CL, Damacena GN, Souza Júnior PRBd, et al. Determinants of self-rated health and the influence of healthy behaviors: results from the National Health Survey, 2013. Rev Bras Epidemiol. 2015;18:33-44.

51. Denton M, Prus S, Walters V. Gender differences in health: a Canadian study of the psychosocial, structural and behavioural determinants of health. Soc Sci Med. 2004;58:2585-600

52. Buvinic M, Medici A, Fernandez E, et al.: Gender Differentials in Health. In: nd, Jamison DT, Breman JG, et al., (eds.): Disease Control Priorities in Developing Countries. Washington (DC). World Bank The International Bank for Reconstruction and Development/The World Bank Group., 2006.
53. Spuling SM, Huxhold O. Wurm S predictors of self-rated health: does education play a role above and beyond age? J Gerontol B Psychol Sci Soc Sci. 2017;72:415-24.

54. Darker CD, Donnelly-Swift E, Whiston $L$, et al. Determinants of self-rated health in an Irish deprived suburban population - a cross-sectional face-toface household survey. 2016;16:767.

55. Bombak AE, Bruce SG. Self-rated health and ethnicity: focus on indigenous populations. Int J Circumpolar Health. 2012;71:18538

56. Borgonovi F, Pokropek A. Education and self-reported health: evidence from 23 countries on the role of years of schooling, cognitive skills and social capital. PLoS One. 2016:11:e0149716.

57. Kim HH. The association between social capital measures and self-reported health among Muslim majority nations. Int J Public Health. 2014:59:749-57.

58. Luchi CA, Peres KG, Bastos $J$, et al. Inequalities in self-rated oral health in adults. Rev Saude Publica. 2013:47:740-51.

59. Chang C-S, Chang FM, Nakagaki H, et al. Comparison of the oral health and self-rated general health status of undergraduate students in Taiwan and Japan. J Dent Sci. 2010;5:221-8.

60. Reissmann DR, John MT, Schierz O, et al. Association between perceived oral and general health. J Dent. 2013;41:581-9.

61. Sanchez-Garcia S, Heredia-Ponce E, Juarez-Cedillo T, et al. Psychometric properties of the General Oral health assessment index (GOHAl) and dental status of an elderly Mexican population. J Public Health Dent. 2010;70:300-7.

62. John MT. Health outcomes reported by dental patients. J Evid Base Dent Pract. 2018;18:332-5.

63. Devi S. Yemeni health under relentless pressure. Lancet. 2018:391:646.

\section{Publisher's Note}

Springer Nature remains neutral with regard to jurisdictional claims in published maps and institutional affiliations.
Ready to submit your research? Choose BMC and benefit from:

- fast, convenient online submission

- thorough peer review by experienced researchers in your field

- rapid publication on acceptance

- support for research data, including large and complex data types

- gold Open Access which fosters wider collaboration and increased citations

- maximum visibility for your research: over $100 \mathrm{M}$ website views per year

At BMC, research is always in progress.

Learn more biomedcentral.com/submissions 